\title{
Effects of Nisin and Lysozyme on Growth Inhibition and Biofilm Formation Capacity of Staphylococcus aureus Strains Isolated from Raw Milk and Cheese Samples
}

\author{
MERT SUDAGIDAN $^{1}$ AND AHMET YEMENICIOĞGLU2*
}

${ }^{1}$ Science and Technology Application and Research Center, Mehmet Akif Ersoy University, 15100 Burdur, Turkey; and ${ }^{2}$ Department of Food Engineering, Izmir Institute of Technology, Gulbahce Campus, Urla 35430, Izmir, Turkey

MS 12-001: Received 2 January 2012/Accepted 7 May 2012

\begin{abstract}
Effects of nisin and lysozyme on growth inhibition and biofilm formation capacity of 25 Staphylococcus aureus strains isolated from raw milk (13 strains) and cheese (12 strains) were studied. Nisin was tested at concentrations between 0.5 and $25 \mu \mathrm{g} /$ $\mathrm{ml}$; the growth of all strains was inhibited at $25 \mu \mathrm{g} / \mathrm{ml}$, but the resistances of strains showed a great variation at lower nisin concentrations. In contrast, lysozyme tested at concentrations up to $5.0 \mathrm{mg} / \mathrm{ml}$ showed no inhibition on the growth of strains. Nisin used at the growth inhibitory concentration prevented the biofilm formation of strains, but strains continued biofilm formation at subinhibitory nisin concentrations. Lysozyme did not affect the biofilm formation of 19 of the strains, but it caused a considerable activation in the biofilm formation capacity of six strains. Twelve of the strains contained both biofilm-related protease genes ( $\operatorname{sp} A, \operatorname{ssp} B$, and $a u r)$ and active proteases; eight of these strains were nisin resistant. These results suggest a potential risk of $S$. aureus growth and biofilm formation when lysozyme is used in the biopreservation of dairy products. Nisin can be used to control growth and biofilm formation of foodborne $S$. aureus, unless resistance against this biopreservative develops.
\end{abstract}

There is growing interest in the use of biopreservation methods that employ natural antimicrobial compounds. Nisin, a well-known bacteriocin obtained from lactic acid bacteria, and lysozyme, an antimicrobial enzyme produced from hen egg white, are among the most promising candidates for use in the biopreservation of food (13). The antimicrobial effect of nisin is due to its cationic nature, which helps it interact with anionic phospholipids at bacterial surfaces to form pores and to dissipate proton motive forces at the bacterial membrane, whereas lysozyme hydrolyzes the peptidoglycan (PG) layer at the bacterial cell walls $(2,5,36)$. Both nisin and lysozyme are effective against different gram-positive bacteria, but they are ineffective against gram-negative bacteria because of the protective lipopolysaccharide layer surrounding their PG layer at the cell walls.

In recent years, the effects of adding nisin and lysozyme to a variety of foods or incorporating them into plastic or biodegradable films intended for antimicrobial food packaging have been extensively studied (43). The dairy industry was one of the first to be interested in using these generally recognized as safe substances. In fact, nisin and lysozyme are currently used effectively in cheeses as an alternative to nitrates to prevent late blowing caused by

\footnotetext{
* Author for correspondence. Tel: + 902327506292; Fax: + 902327506296;

E-mail: ahmetyemenicioglu@iyte.edu.tr.
}

Clostridium tyrobutyricum $(8,38)$. Nisin is also used in various cheese and milk products to inhibit gram-positive pathogenic bacteria, including Clostridium botulinum, Listeria monocytogenes, and Staphylococcus aureus (13, $31,35,37)$.

S. aureus is a common cause of confirmed food poisoning and gastroenteritis resulting from the consumption of contaminated food (24). The poisoning caused by this bacterium is frequently associated with raw milk and traditional cheeses made from unpasteurized milk, since the breasts of dairy cows can be a reservoir of enterotoxigenic $S$. aureus strains, a significant cause of mastitis $(18,29,31)$. One problem in controlling risks caused by $S$. aureus comes from its capacity to produce biofilms formed by an extracellular polysaccharide matrix and biofilm-associated proteins (BAPs) (11). Because the biofilm formed by the bacteria increases its resistance to mechanical cleaning and disinfectants, the bacteria can spread into different parts of processing environments and subsequently contaminate food $(7,9)$. Thus, cheese from heat-treated milk and whey might also carry significant risks unless processing equipment is decontaminated effectively and unless the curd obtained postheating is handled and stored properly $(21,37)$. Biofilm is also an important virulence factor because it protects bacteria from opsonophagocytosis and antibiotics $(14,25)$. BAP formation is a characteristic of mastitis-associated staphylococcal isolates (12). Recent 
findings have supported the hypothesis that the phenotype of $S$. aureus can change from adhesive to invasive when it ceases protein-dependent biofilm formation and initiates mechanisms that cause biofilm degradation (25). There is increasing evidence that the biofilm formation process and virulence of $S$. aureus are controlled by different types of extracellular proteases, such as V8 protease (SspA), staphopain B (SspB), and aureolysin (Aur), which are serine protease, cysteine protease, and metalloprotease secreted by staphylococci, respectively (14). Martí et al. (25) showed a close relation of Aur and SspA overexpression and the degradation of BAP and cessation of biofilm formation in $S$. aureus. In addition, Shaw et al. (39) investigated the effects of mutations on $S$. aureus protease genes and reported the attenuation of the virulence of bacteria after insertional inactivation of $s s p A$ and $s s p B$ genes.

Studies have shown the nisin and lysozyme resistance of $S$. aureus strains $(3,4,20,27)$. Recently, the lysozyme resistance of $S$. aureus has been shown to be related to the O-acylation of its peptidoglycan at the cell walls by an integral membrane protein, OatA (3), while resistance of $S$. aureus against nisin has been attributed to its reduced hydrophobicity and increased net positive charge following contact with this cationic peptide (26). However, there are no studies related to variations in nisin and lysozyme resistances of foodborne $S$. aureus strains isolated from milk and dairy products. Moreover, there are few data available about the effects of these biopreservatives on the biofilm formation capacity of $S$. aureus and the possible roles of biofilm formation in its nisin and lysozyme resistance mechanisms. The primary objective of this study was to determine the effects of nisin and lysozyme on the growth inhibition and biofilm formation capacity of $S$. aureus strains isolated from raw milk and cheese samples. The genes controlling synthesis of proteases mediating protease activity and biofilm formation of bacteria were also investigated to better understand the possible causes of the varying biofilm formation capacity of the strains. The present study will provide a deeper elucidation of potential risks associated with foodborne $S$. aureus and the use of biopreservatives in dairy products.

\section{MATERIALS AND METHODS}

Biopreservatives. Lysozyme ( $\geq 40,000 \mathrm{U} / \mathrm{mg}$ of protein) from hen egg white and nisin from Lactococcus lactis (2.5\%) were obtained from Sigma (St. Louis, MO).

Bacterial strains. The $S$. aureus strains (13 strains from raw milk samples and 12 strains from cheese samples) were previously isolated in Turkey and were characterized with molecular tests (1).

Bacterial growth and biofilm formation. The effects of biopreservatives on $S$. aureus strains were analyzed in tryptic soy broth (TSB; Merck, Darmstadt, Germany) at $\mathrm{pH} 6.5$ by spectrophotometric monitoring of turbidity formed by bacterial growth. The strains were grown on tryptic soy agar (TSA; Merck) at $37^{\circ} \mathrm{C}$ overnight, and the colonies were suspended in $10 \mathrm{ml}$ of $0.9 \%$ (wt/vol) $\mathrm{NaCl}$. Bacterial suspensions were adjusted to McFarland $0.5\left(\cong 5 \times 10^{10} \mathrm{CFU} / \mathrm{ml}\right)$ using a densitometer (Den1, HVD Life Sciences, Austria) before being mixed with biopreservatives. One hundred eighty microliters of TSB containing nisin (at $0.5,2.5,12.5$, and $25 \mu \mathrm{g} / \mathrm{ml}$ ) or lysozyme (at 1, 2, 3, 4, and $5 \mathrm{mg} / \mathrm{ml}$ ) and $20 \mu \mathrm{l}$ of test strain were then mixed into a flat-bottom 96-well plate. The plate was incubated at $37^{\circ} \mathrm{C}$ for $24 \mathrm{~h}$ within the constant temperature plate holder of a microplate reader (Varioskan Flash, Thermo, Finland), and absorbance of well contents was determined at $600 \mathrm{~nm}$ every $15 \mathrm{~min}$. The controls and cultures containing biopreservatives were tested in triplicate wells at each concentration, and averages of absorbance values versus time (minutes) were plotted to form growth curves. The following formula was used to calculate degree of inhibition: \% inhibition = $100-[(\mathrm{S} 1 / \mathrm{S} 2) \times 100]$, where $\mathrm{S} 1$ is the slope of the best-fitting curve for a culture with biopreservatives and S2 is the slope of the best-fitting curve for the control (culture) at the linear growth phase of absorbance-time curves coming after lag periods. The lag period (minutes), which shows the delay in growth due to the effect of the biopreservative, was determined by subtracting the intercept of the best-fitting curve at the $x$ axis for the linear growth phase of culture with a biopreservative from the intercept of the control.

At the end of the growth inhibition test (after $24 \mathrm{~h}$ of incubation at $37^{\circ} \mathrm{C}$ ), the plate contents were tested for biofilm-forming capacity (40). The plates were emptied and washed five times with $200 \mu \mathrm{l}$ of phosphate-buffered saline $(\mathrm{pH} 7.0)$. The biofilm adhered at the surfaces of wells was then fixed with $200 \mu \mathrm{l}$ of methanol and incubated for $15 \mathrm{~min}$. The wells were then emptied and dried at $55^{\circ} \mathrm{C}$ for $1 \mathrm{~h}$. The biofilm was stained with $200 \mu \mathrm{l}$ of crystal violet for $5 \mathrm{~min}$, and excess dye was washed off with water. The plate was dried, the absorbed crystal violet within wells was dissolved with $200 \mu \mathrm{l}$ of $33 \%$ (vol/vol) glacial acetic acid, and optical densities of the well contents were measured at $590 \mathrm{~nm}$ using the microplate reader specified above. Absorbance values $\leq 0.1$ were not considered to be color formed by biofilm since such low values were also formed by completely inhibited bacteria.

Detection of protease genes and active extracellular proteases. The presence of protease genes $(\operatorname{ssp} A, \operatorname{ssp} B$, and $a u r)$ was determined by PCR using the primers as described by Karlsson and Arvidson (23). Bacterial genomic DNA isolation was carried out according to Sudagidan et al. (42). The reactions were performed in $50 \mu \mathrm{l}$ of reaction mixture containing $1.2 \mathrm{U}$ of Taq DNA polymerase (Fermentas, Vilnius, Lithuania), $5 \mu \mathrm{l}$ of $10 \times$ reaction buffer $(750 \mathrm{mM}$ Tris- $\mathrm{HCl}$ at $\mathrm{pH} 8.8$ containing $200 \mathrm{mM}$ $\left(\mathrm{NH}_{4}\right)_{2} \mathrm{SO}_{4}, 0.1 \%$ [vol/vol] Tween $\left.20,1.5 \mathrm{mM} \mathrm{MgCl} 2\right), 10 \mu \mathrm{M}$ of each of the primers (Metabion, Martinsried, Germany), $0.2 \mathrm{mM}$ each of the four deoxynucleoside triphosphates (Fermentas), and $5 \mu \mathrm{l}$ of the bacterial lysate as the DNA template. The PCR products were resolved in $1.5 \%$ (wt/vol) agarose gel electrophoresis in $1 \times$ TAE buffer $(0.04 \mathrm{M}$ Tris-acetate, $0.001 \mathrm{M}$ EDTA). PCR experiments were done twice for each strain. Extracellular protease production of the strains was determined on the growth media containing casein as substrate (41). The strains were spotted on casein agar plates and incubated at $37^{\circ} \mathrm{C}$ for at least 3 days. Clear zone formation around the spotted areas on agar after treatment with $5 \%(\mathrm{vol} / \mathrm{vol})$ trichloroacetic acid showed the presence of the active extracellular proteases.

Statistical analysis. Statistical analysis was carried out by analysis of variance with a significance threshold of $P<0.05$, as determined by Fisher's least significant difference test method using Minitab 15 software.

\section{RESULTS AND DISCUSSION}

Lysozyme tested at concentrations between 1 and $5 \mathrm{mg} /$ $\mathrm{ml}$ did not show a considerable growth inhibitory effect on 

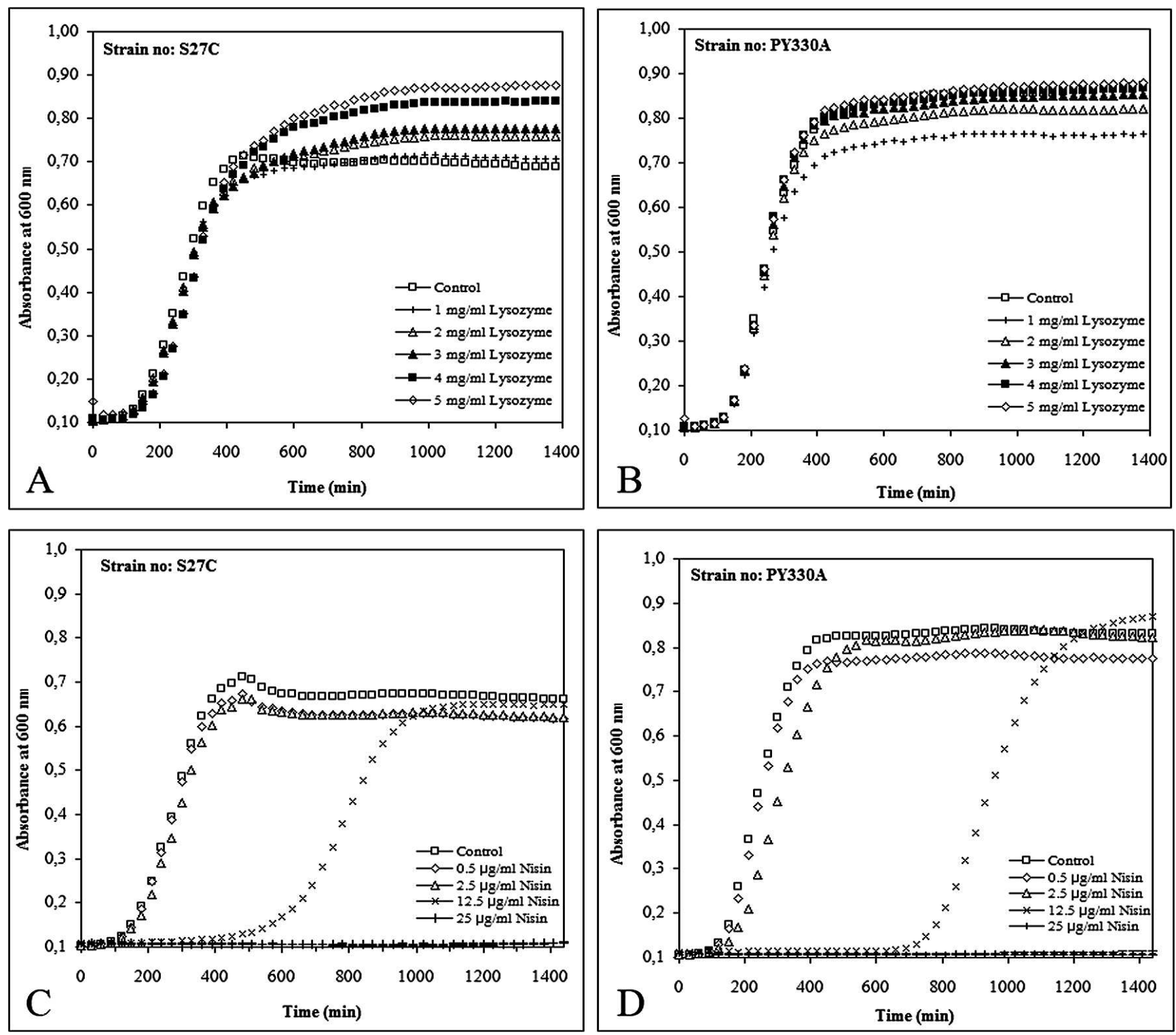

FIGURE 1. Growth curves of selected S. aureus strains with different concentrations of lysozyme $(A, B)$ or nisin $(C, D)$.

S. aureus strains. Also, no measurable lag periods were observed in the growth curves of strains in the presence of lysozyme. However, in nine strains isolated from raw milk samples (S170AY, S205Y, S267, S137AY, S158B, S292, S4BY, S133B, and S27C) and in four strains isolated from cheese samples (PY96B, PY1, PY2, and PY3), the presence of lysozyme prolonged the logarithmic growth phase and increased the absorbance values reached at the stationary phase (Fig. 1A). The absorbance values reached at the stationary phase of the indicated strains increased as the lysozyme concentration increased. However, more detailed actual plate counts are needed to report a limited growth activating effect of lysozyme on $S$. aureus. These changes in the growth curves were not observed in the remaining 12 strains. Instead, in the presence of lysozyme, these strains had growth curves similar to that of the control, or showed insignificant reductions in their growth rates (Fig. 1B). These results support the hypothesis that lysozyme resistance is an important virulence factor for S. aureus (15).
Nisin at the $25-\mu \mathrm{g} / \mathrm{ml}$ concentration inhibited the growth of all S. aureus strains (Fig. 1C and 1D). However, the strains varied considerably in their resistance to nisin at subinhibitory concentrations (Table 1). The nisin resistances of strains were ranked by the degree of their growth inhibition at different nisin concentrations and by lag periods in their growth curves caused by this agent. In 2 of 13 strains isolated from raw milk (S170AY and S205Y), the bacteria showed high susceptibility to nisin, even at $0.5 \mu \mathrm{g}$ of nisin per ml. Four strains (S267, S35A, S137AY, and $\mathrm{S} 48 \mathrm{~A}$ ) showed moderate resistance and were inhibited at $12.5 \mu \mathrm{g}$ of nisin per ml. The remaining seven strains, isolated from raw milk, were highly nisin resistant, and $25 \mu \mathrm{g}$ of nisin per ml was needed to inhibit their growth completely. In contrast, 7 of 12 strains isolated from cheese samples showed moderate resistance against nisin and a nisin concentration of $12.5 \mu \mathrm{g} / \mathrm{ml}$ was needed for their complete inhibition. The only strain of cheese isolates highly susceptible to nisin was PY96B, which was inhibited at 
TABLE 1. Nisin resistances of S. aureus strains ranked by considering lag periods and inhibitions in their growth ${ }^{a}$

\begin{tabular}{|c|c|c|c|c|c|c|}
\hline \multirow[b]{2}{*}{ Strain no. } & \multicolumn{2}{|c|}{$0.5 \mu \mathrm{g}$ of $\mathrm{nisin} / \mathrm{ml}$} & \multicolumn{2}{|c|}{$2.5 \mu \mathrm{g}$ of $\mathrm{nisin} / \mathrm{ml}$} & \multicolumn{2}{|c|}{$12.5 \mu \mathrm{g}$ of $\mathrm{nisin} / \mathrm{ml}$} \\
\hline & Lag (min) & Inhibition (\%) & Lag (min) & Inhibition (\%) & Lag (min) & Inhibition (\%) \\
\hline \multicolumn{7}{|c|}{ Strains isolated from raw milk } \\
\hline S170AY & - & -100 & - & -100 & - & -100 \\
\hline S205Y & - & -100 & - & -100 & - & -100 \\
\hline S267 & $85 \pm 6.4 c^{b}$ & $-53 \pm 3.9 \mathrm{E}$ & $394 \pm 88 \mathrm{AB}$ & $-37 \pm 13 \mathrm{HI}$ & - & -100 \\
\hline $\mathrm{S} 35 \mathrm{~A}$ & $34 \pm 1.2 \mathrm{D}$ & $-5.4 \pm 2.7 \mathrm{D}$ & $362 \pm 17$ в & $-48 \pm 5.6 \mathrm{I}$ & - & -100 \\
\hline S137AY & $20 \pm 5.9 \mathrm{DE}$ & $-7.9 \pm 5.2 \mathrm{D}$ & $78 \pm 15 \mathrm{DE}$ & $-25 \pm 3.9 \mathrm{FG}$ & - & -100 \\
\hline S48A & $0.8 \pm 3.4 \mathrm{FG}$ & $-6.2 \pm 1.5 \mathrm{D}$ & $31 \pm 1.7 \mathrm{EF}$ & $-12 \pm 2.7 \mathrm{BCDE}$ & - & -100 \\
\hline S15A & $4.2 \pm 1.2 \mathrm{FG}$ & $-2.4 \pm 0.0$ вСD & $53 \pm 9.1 \mathrm{DEF}$ & $-25 \pm 5.0 \mathrm{FGH}$ & $558 \pm 23$ в & $-51 \pm 17 \mathrm{BC}$ \\
\hline S158B & $12 \pm 1.8 \mathrm{EF}$ & $-2.7 \pm 3.1$ вСD & $38 \pm 3.2 \mathrm{EF}$ & $-13 \pm 3.1 \mathrm{BCDE}$ & $583 \pm 22$ в & $-50 \pm 16$ вс \\
\hline S292 & $5.2 \pm 1.4 \mathrm{FG}$ & $3.7 \pm 1.6 \mathrm{ABC}$ & $16 \pm 1.2 \mathrm{~F}$ & $-0.93 \pm 3.2 \mathrm{AB}$ & $531 \pm 64$ вс & $-47 \pm 6.0 \mathrm{ABC}$ \\
\hline S4By & $6.0 \pm 0.71 \mathrm{FG}$ & $1.8 \pm 3.2 \mathrm{ABC}$ & $19 \pm 0.82 \mathrm{EF}$ & $-6.4 \pm 5.7 \mathrm{ABCDE}$ & $464 \pm 9.2 \mathrm{CD}$ & $-48 \pm 11 \mathrm{ABC}$ \\
\hline S133B & $10 \pm 2.4 \mathrm{EFG}$ & $4.9 \pm 3.4 \mathrm{ABC}$ & $24 \pm 3.5 \mathrm{EF}$ & $3.9 \pm 3.4 \mathrm{~A}$ & $405 \pm 22 \mathrm{D}$ & $-58 \pm 3.4$ вС \\
\hline S133A & $7.9 \pm 1.9 \mathrm{EFG}$ & $2.6 \pm 2.6 \mathrm{ABC}$ & $23 \pm 3.1 \mathrm{EF}$ & $-2.6 \pm 2.6 \mathrm{ABC}$ & $435 \pm 10 \mathrm{D}$ & $-34 \pm 5.3 \mathrm{AB}$ \\
\hline $\mathrm{S} 27 \mathrm{C}$ & - & $-2.6 \pm 2.2 \mathrm{вCD}$ & $12 \pm 3.0 \mathrm{~F}$ & $-2.6 \pm 2.2 \mathrm{ABC}$ & $296 \pm 11 \mathrm{E}$ & $-35 \pm 3.9 \mathrm{AB}$ \\
\hline \multicolumn{7}{|c|}{ Strains isolated from cheese } \\
\hline PY96B & $207 \pm 34 \mathrm{~A}$ & $-23 \pm 8.5 \mathrm{E}$ & - & -100 & - & -100 \\
\hline PY3 & $18 \pm 2.6 \mathrm{DE}$ & $-2.8 \pm 1.6$ вСD & $293 \pm 15 \mathrm{C}$ & $-18 \pm 13 \mathrm{EF}$ & - & -100 \\
\hline PY192A & $17 \pm 2.2 \mathrm{DEF}$ & $0.0 \mathrm{ABCD}$ & $69 \pm 12 \mathrm{DE}$ & $-14 \pm 1.6 \mathrm{CDEF}$ & - & -100 \\
\hline PY417A & $5.8 \pm 3.9 \mathrm{FG}$ & $-4.6 \pm 4.2 \mathrm{CD}$ & $45 \pm 7.8 \mathrm{DEF}$ & $-14 \pm 3.2 \mathrm{CDEF}$ & - & -100 \\
\hline PY280 & $6.6 \pm 1.7 \mathrm{EFG}$ & $1.7 \pm 3.0 \mathrm{ABC}$ & $36 \pm 2.3 \mathrm{EF}$ & $-6.0 \pm 1.5 \mathrm{ABCD}$ & - & -100 \\
\hline PY31A & $4.7 \pm 1.6 \mathrm{FG}$ & $1.8 \pm 1.5 \mathrm{ABC}$ & $16 \pm 5.1 \mathrm{~F}$ & $-11 \pm 1.5 \mathrm{BCDE}$ & - & -100 \\
\hline PY1 & $118 \pm 3.0$ в & $-8.7 \pm 4.4 \mathrm{D}$ & $431 \pm 29 \mathrm{~A}$ & $4.4 \pm 4.4 \mathrm{~A}$ & - & -100 \\
\hline PY30C SARI & - & $-1.0 \pm 3.0 \mathrm{ABCD}$ & $12 \pm 1.0 \mathrm{~F}$ & $-3.0 \pm 1.7 \mathrm{ABCD}$ & - & -100 \\
\hline PY2 & $4.8 \pm 2.8 \mathrm{FG}$ & $-1.1 \pm 5.0 \mathrm{ABCD}$ & $26 \pm 2.8 \mathrm{EF}$ & $2.2 \pm 5.0 \mathrm{~A}$ & $807 \pm 45 \mathrm{~A}$ & $-65 \pm 15 \mathrm{C}$ \\
\hline PY134A & $16 \pm 0.9 \mathrm{DEF}$ & $8.2 \pm 3.5 \mathrm{~A}$ & $93 \pm 10 \mathrm{D}$ & $-37 \pm 1.8 \mathrm{GHI}$ & $561 \pm 9.2$ в & $-44 \pm 4.7 \mathrm{ABC}$ \\
\hline PY153C & $5.5 \pm 1.5 \mathrm{FG}$ & $6.0 \pm 0.0 \mathrm{AB}$ & $15 \pm 4.1 \mathrm{~F}$ & $-6.9 \pm 2.6 \mathrm{ABCDE}$ & $473 \pm 65 \mathrm{CD}$ & $-51 \pm 15$ вС \\
\hline PY330A & $12 \pm 1.3 \mathrm{EF}$ & $3.2 \pm 0.0 \mathrm{ABC}$ & $42 \pm 2.1 \mathrm{DEF}$ & $-15 \pm 1.9 \mathrm{DEF}$ & $536 \pm 43$ вс & $-24 \pm 11 \mathrm{~A}$ \\
\hline
\end{tabular}

${ }^{a}$ All strains were inactivated at $25 \mu \mathrm{g}$ of nisin per $\mathrm{ml}$.

${ }^{b}$ Values with different letters in the same column are significantly different $(P<0.05)$.

$2.5 \mu \mathrm{g}$ of nisin per ml, while the remaining four strains (PY2, PY134A, PY153C, and PY330A) showed more nisin resistance and needed $25 \mu \mathrm{g}$ of nisin per $\mathrm{ml}$ for complete inhibition.

In comparison with other studies related to nisin resistance of $S$. aureus strains, the MIC of $25 \mu \mathrm{g}$ of nisin per $\mathrm{ml}$ determined for 11 of 25 strains in this study was higher than MICs reported for S. aureus strain $40(0.54 \mu \mathrm{g}$ of nisin per ml) and its nisin-resistant mutant ( $2.2 \mu \mathrm{g}$ of nisin per ml) (27). The nisin-resistant strains determined in this work also required higher MICs than 34 of 35 antibioticresistant $S$. aureus strains, which required a maximum MIC of $8.3 \mu \mathrm{g}$ of nisin per $\mathrm{ml}$ (one strain required a MIC of $>8.3 \mu \mathrm{g}$ of nisin per ml) (32). However, S. aureus CECT 4013 (34) and S. aureus Sa113 (30), requiring MICs of 25 and $23 \mu \mathrm{g}$ of nisin per $\mathrm{ml}$, respectively, showed similar resistance to the nisin-resistant strains in this study. In contrast, the strains tested in this work were considerably less nisin resistant than $S$. aureus Sa9R, a nisin-adapted strain requiring a MIC greater than $100 \mu \mathrm{g}$ of nisin per $\mathrm{ml}$ (26). An adaptation to nisin was also observed for $L$. monocytogenes mutants, with resistance to nisin up to 50 $\mu \mathrm{g} / \mathrm{ml}$ (mutants were detected at frequencies of $10^{-6}$ to $10^{-8}$ ) (19). Peschel et al. (30) reported that the nisin resistances of $S$. aureus cells could be related to the amount of positively charged D-alanine esters in their cell wall teichoic acids and hypothesized that the increased positive charge at the bacterial cell walls was an important part of their resistance mechanism against cationic peptides including nisin. Recently, Martínez et al. (26) supported this hypothesis; they detected a net positive charge increase in a nisin-adapted S. aureus strain. However, these authors also detected a reduction in hydrophobicity of the nisin-adapted strain. There is also evidence that the nisin resistance of some $S$. aureus strains is related to a nisin-inactivating enzyme, nisinase (6). Jarvis (22) showed the presence of nisin-inactivating enzymes in nisin-resistant Bacillus spp., but Grade et al. (17) attributed the nisin resistance of Streptococcus thermophilus INIA 463 to a thickening of its cell wall following nisin contact of this bacterium. These results clearly showed the presence of different nisin resistance mechanisms in bacteria and the need for further studies to investigate the existence or contribution of each mechanism in the nisin resistance of $S$. aureus. Further isolation and screening studies are also needed in dairy products to determine the frequency of isolation of nisinresistant strains. According to the Codex Alimentarius, nisin can be applied to ripened cheese and whey protein cheese at a maximum level of $12 \mu \mathrm{g} / \mathrm{g}$ (16). This nisin level seems 


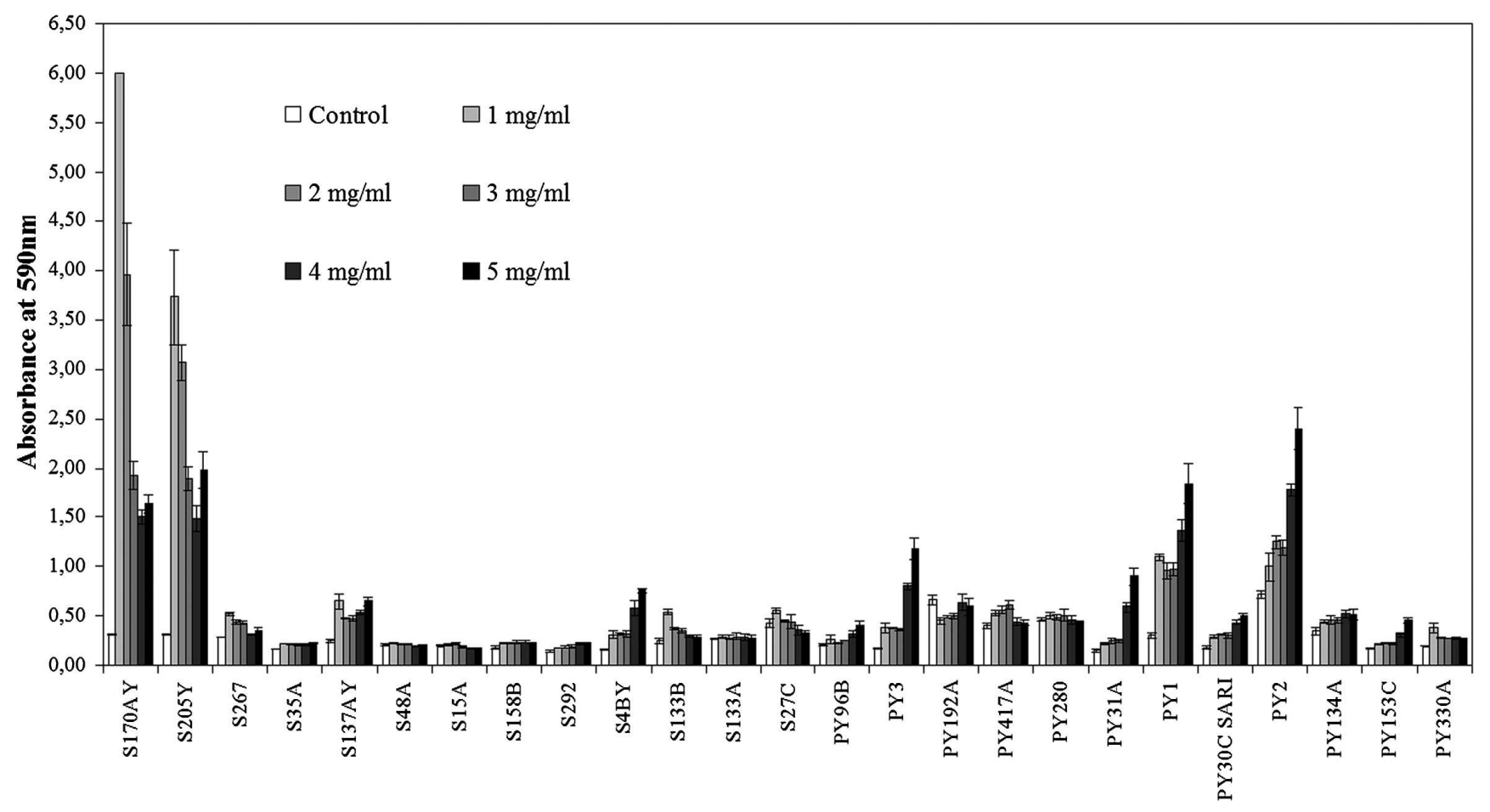

FIGURE 2. Effect of lysozyme on biofilm formation of $\mathrm{S}$. aureus strains.

risky considering the nisin resistance of $S$. aureus strains studied in this work or reported in the literature. However, the good manufacturing practice level of $250 \mathrm{ppm}(250 \mu \mathrm{g} /$ g) in the finished processed cheese product determined by the British Standards Institution and approved by the U.S. Food and Drug Administration (FDA) was quite a safe nisin level to prevent poisoning caused by $S$. aureus in dairy products (10).
The effects of lysozyme and nisin on biofilm formation capacity of $25 \mathrm{~S}$. aureus strains are shown in Figures 2 and 3. Lysozyme either did not considerably affect or only slightly increased the biofilm formation capacity in 19 of 25 strains. In contrast, the enzyme caused a considerable activation in the biofilm formation capacity of six strains (PY1, PY2, PY3, PY31A, S170AY, and S205Y). Increased lysozyme concentration caused a considerable increase in

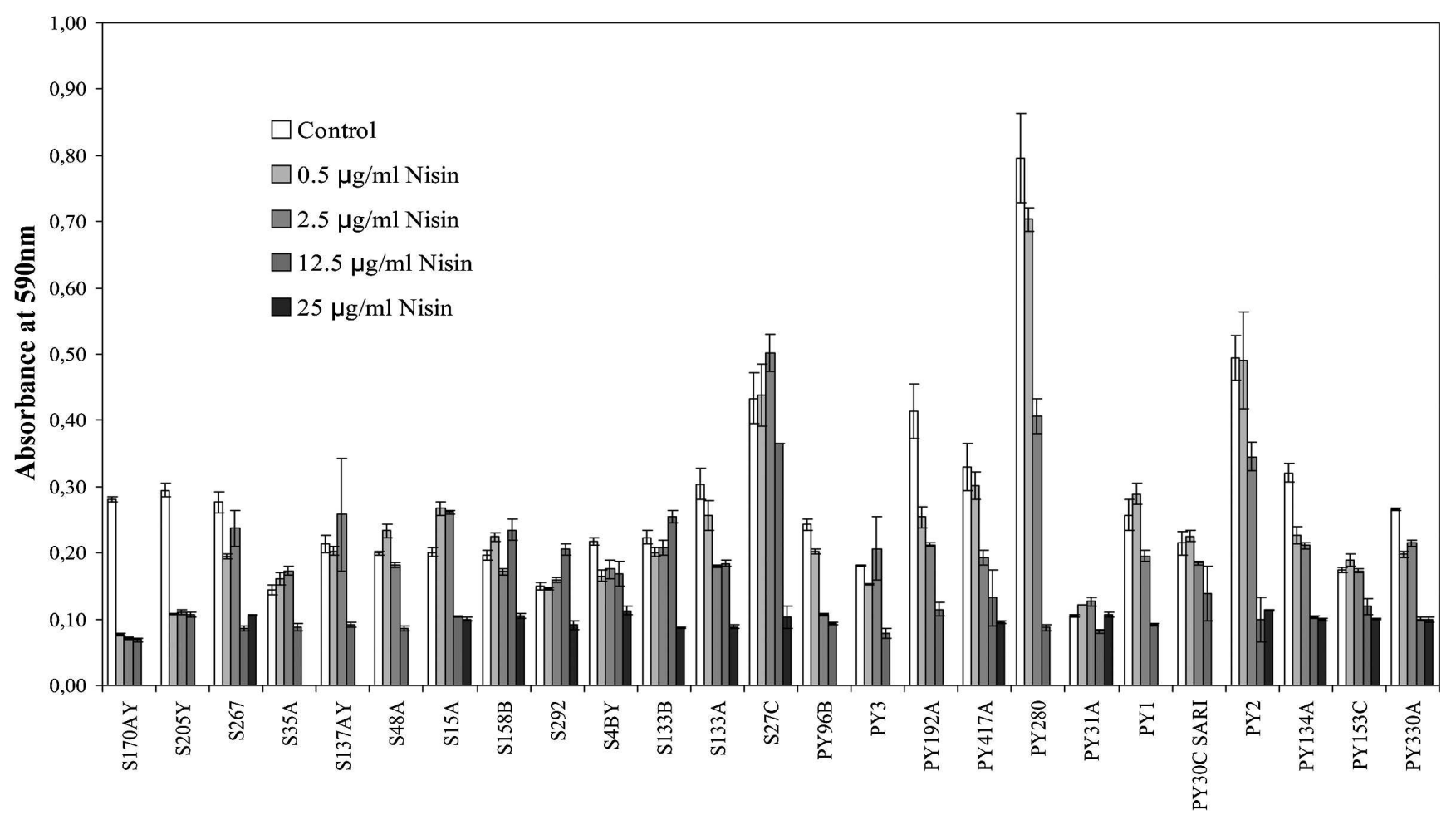

FIGURE 3. Effect of nisin on biofilm formation of S. aureus strains. 
TABLE 2. Biofilm-related protease genes and protease activity of S. aureus strains

\begin{tabular}{|c|c|c|c|c|}
\hline \multirow[b]{2}{*}{ Strain no. } & \multicolumn{3}{|c|}{ Protease genes } & \multirow[b]{2}{*}{ Protease activity ${ }^{a}$} \\
\hline & $\operatorname{ssp} A$ & $\operatorname{ssp} B$ & aur & \\
\hline \multicolumn{5}{|c|}{ Strains isolated from raw milk } \\
\hline S170AY & + & - & + & - \\
\hline S205Y & + & - & + & - \\
\hline S267 & + & + & + & + \\
\hline $\mathrm{S} 35 \mathrm{~A}$ & + & + & + & - \\
\hline S137AY & + & + & + & - \\
\hline $\mathrm{S} 48 \mathrm{~A}$ & + & + & + & - \\
\hline S15A & + & + & + & + \\
\hline S158B & + & + & + & + \\
\hline S292 & + & + & + & + \\
\hline S4BY & + & + & + & - \\
\hline S133B & + & + & + & + \\
\hline S133A & + & + & + & + \\
\hline S27C & + & - & - & + \\
\hline \multicolumn{5}{|c|}{ Strains isolated from cheese } \\
\hline PY96B & + & + & + & + \\
\hline PY3 & + & + & + & - \\
\hline PY192A & + & + & + & - \\
\hline PY417A & + & + & + & + \\
\hline PY280 & + & + & + & - \\
\hline PY31A & + & + & + & + \\
\hline PY1 & + & + & + & - \\
\hline PY30C SARI & + & + & + & + \\
\hline PY2 & + & + & + & - \\
\hline PY134A & + & + & + & - \\
\hline PY153C & + & + & + & + \\
\hline PY330A & + & + & + & + \\
\hline
\end{tabular}

${ }^{a}+$, presence of clearly identified zones $(\geq 1 \mathrm{~cm}) ;-$, absence of clearly identified zones $(\geq 1 \mathrm{~cm})$.

the biofilm formation capacity of PY1, PY2, PY3, and PY31A. In strains S170AY and S205Y, the highest amount of biofilm was formed with $1 \mathrm{mg} / \mathrm{ml}$ lysozyme, but the biofilm formation of these strains reduced as lysozyme concentration increased. The lysozyme did not cause a considerable change in the growth curve of PY31A, but in the remaining five strains the logarithmic growth phase was prolonged in the presence of lysozyme. These results suggest that biofilm formation capacity would be affected by the changed growth kinetics of bacteria in the presence of lysozyme. However, further studies are also needed to investigate if lysozyme activity at the bacterial surface triggers upregulation of gene synthesis for biofilm formation.

On the other hand, the presence of nisin at growth inhibitory concentrations reduced or inhibited the biofilm formation considerably (Fig. 3). Although most of the strains formed amounts of biofilm comparable to that in controls at subinhibitory nisin concentrations, no considerable activation occurred in biofilm formation capacity as was observed with lysozyme. No biofilm formation was detected for PY2 and PY280 strains; they showed the lowest nisin resistance and were inactivated even at $0.5 \mu \mathrm{g} / \mathrm{ml}$ nisin. We found no data in the literature related to biofilm formation capacity of different $S$. aureus strains in the presence of nisin. However, studies were conducted to incorporate nisin or immobilize it onto different supports to obtain materials having antimicrobial and biofilm inhibitory effects against bacteria, including $S$. aureus $(28,33)$.

The protease-encoding genes ( $s p A$, sspB, and $a u r)$ and protease activity of strains were also investigated since specific extracellular proteases such as SspA, SspB, and Aur secreted by $S$. aureus might cause degradation of its proteinbased biofilms and start its phenotypic change from adhesive to invasive. As seen in PCR results (Table 2), all strains contained the sspA gene. S170AY and S205Y strains lacked only $s s p B$, whereas $\mathrm{S} 27 \mathrm{C}$, the most nisin-resistant strain isolated from raw milk, lacked genes of aur and $s s p B$. On the other hand, the active proteases were detected mainly in nisin-resistant strains. The results indicated that six of seven nisin-resistant strains from raw milk samples, and two of four nisin-resistant strains from cheese samples, contained active extracellular proteases. In contrast, five strains (S170AY, S205Y, PY1, PY2, and PY3) that formed extensive amounts of biofilm in the presence of lysozyme lacked active proteases. Further studies using more strains are needed to report a potential correlation between the protease activity of $S$. aureus and its ability to form biofilms. However, these preliminary results suggest that the lack of active proteases prevented the degradation of BAP formed by these bacteria and that this improved their biofilm formation capacity.

In conclusion, the presence of lysozyme did not inhibit $S$. aureus strains isolated from raw milk and cheese samples and it increased the biofilm formation capacity of some strains. Nisin, at an appropriately high concentration, was effective to inhibit the growth of all strains completely, but it could not prevent biofilm formation at subinhibitory concentrations. Most of the nisin-resistant strains contained biofilm-related protease genes and active proteases, while most strains that formed extensive amounts of biofilm in the presence of lysozyme lacked active proteases. This study clearly showed the risk of biofilm formation by $S$. aureus in dairy products containing lysozyme as a biopreservative. The current good manufacturing practice limits of nisin in finished cheese products suggested by the FDA $(250 \mu \mathrm{g} / \mathrm{g})$ could be safe to inactivate $S$. aureus in dairy products. However, the maximum nisin limits suggested by the Food and Agriculture Organization and the World Health Organization $(12 \mu \mathrm{g} / \mathrm{g})$ may be risky for inactivation of the nisin-resistant strains. Further studies are needed to regularly monitor nisin-resistant $S$. aureus strains in dairy products and investigate the possible correlations among nisin resistance, biofilm formation capacity, and protease activity.

\section{ACKNOWLEDGMENTS}

The authors thank Associate Professor Dr. Ali Aydin (Istanbul University) for providing bacterial strains used in this study and research assistant Levent Aydemir (Izmir Institute of Technology) for statistical analysis. We appreciate Izmir Institute of Technology, Biotechnology and Bioengineering Research and Applications Center (BIYOMER) for providing the laboratory facilities for this study. 


\section{REFERENCES}

1. Aydin, A., K. Muratoglu, M. Sudagidan, K. Bostan, B. Okuklu, and S. Harsa. 2011. Prevalence and antibiotic resistance of foodborne Staphylococcus aureus isolates in Turkey. Foodborne Pathog. Dis. 8:63-69.

2. Bauer, R., and L. M. T. Dicks. 2005. Mode of action of lipid IItargeting lantibiotics. Int. J. Food Microbiol. 101:201-216.

3. Bera, A., S. Herbert, A. Jakob, W. Vollmer, and F. Götz. 2005. Why are pathogenic staphylococci so lysozyme resistant? The peptidoglycan O-acetyltransferase OatA is the major determinant for lysozyme resistance of Staphylococcus aureus. Mol. Microbiol. 55:778-787.

4. Blake, K. L., C. P. Randall, and A. J. O’Neill. 2011. In vitro studies indicate a high resistance potential for the lantibiotic nisin in Staphylococcus aureus and define a genetic basis for nisin resistance. Antimicrob. Agents Chemother. 55:2362-2368.

5. Bruno, M. E. C., A. Kaiser, and T. J. Montville. 1992. Depletion of proton motive force by nisin in Listeria monocytogenes cells. Appl. Environ. Microbiol. 58:2255-2259.

6. Carlson, S., and H. M. Bauer. 1957. Nisin, ein antibakterieller wirkstoff aus Streptococcus lactis unter berucksichtigung des resistenz problems. Arch. Hyg. Bakteriol. 141:445-459.

7. Carpentier, B., and O. Cerf. 1993. Biofilms and their consequences, with particular reference to hygiene in the food industry. J. Appl. Bacteriol. 75:499-511.

8. Chen, H., and D. G. Hoover. 2003. Bacteriocins and their food applications. J. Food Sci. 2:82-100.

9. Cloete, T. E. 2003. Resistance mechanisms of bacteria to antimicrobial compounds. Int. Biodeterior. Biodegrad. 51:277-282.

10. Code of Federal Regulations. 2010. 21 CFR 184.1538, Title 21, vol. 3. Direct food substances affirmed as generally recognized as safe. Available at: http://www.accessdata.fda.gov/scripts/cdrh/cfdocs/ cfcfr/CFRSearch.cfm?fr =184.1538. Accessed 27 July 2011.

11. Cucarella, C., C. Solano, J. Valle, B. Amorena, Í. Lasa, and J. R. Penadés. 2001. Bap, a Staphylococcus aureus surface protein involved in biofilm formation. J. Bacteriol. 183:2888-2896.

12. Cucarella, C., M. Á. Tormo, C. Úbeda, M. P. Trotonda, M. Monzón, C. Peris, B. Amorena, Í. Lasa, and J. R. Penadés. 2004. Role of biofilm-associated protein Bap in the pathogenesis of bovine Staphylococcus aureus. Infect. Immun. 72:2177-2185.

13. Davidson, P. M., and M. A. Harrison. 2002. Resistance and application to food antimicrobials, sanitizers, and other process controls. Food Technol. 56:69-78.

14. Dubin, G. 2003. Defense against own arms: staphylococcal cysteine proteases and their inhibitors. Acta Biochim. Pol. 50:715-724.

15. Fedtke, I., F. Götz, and A. Peschel. 2004. Bacterial evasion of innate host defenses-the Staphylococcus aureus lesson. Int. J. Med. Microbiol. 294:189-194.

16. Food and Agriculture Organization of the United Nations and World Health Organization. 2010. GSFA provisions for nisin. Available at: http: //www.codexalimentarus.net/gsfaonline/additives/detaills.html?id =1. Accessed 27 July 2011.

17. Grade, S., M. Avila, and M. Nunez. 2004. Fast induction of nisin resistance in Streptococcus thermophilus INIA 463 during growth in milk. Int. J. Food Microbiol. 96:165-172.

18. Hamama, A., N. El Hankouri, and M. El Ayadi. 2002. Fate of enterotoxigenic Staphylococcus aureus in the presence of nisinproducing Lactococcus lactis strain during manufacture of Jben, a Moroccan traditional fresh cheese. Int. Dairy J. 12:933-938.

19. Harris, L. J., H. P. Fleming, and T. R. Klaenhammer. 1991. Sensitivity and resistance of Listeria monocytogenes ATCC 19115, Scott A and UAL500 to nisin. J. Food Protog. 54:836-840.

20. Herbert, S., A. Bera, C. Nerz, D. Graus, A. Paschel, C. Goerke, M. Meehl, A. Cheung, and F. Götz. 2007. Molecular basis of resistance to muramidase and cationic antimicrobial peptide activity of lysozyme in Staphylococci. PLoS Pathog. 3:981-993.

21. Jakobsen, R. A., R. Heggeb $\varnothing$, E. B. Sunde, and M. Skjervheim. 2011. Staphylococcus aureus and Listeria monocytogenes in Norwegian raw milk cheese production. Food Microbiol. 28:492-496.

22. Jarvis, B. 1967. Resistance to nisin and production of nisininactivating enzymes by several Bacillus species. J. Gen. Microbiol. 47:33-48.
23. Karlsson, A., and S. Arvidson. 2002. Variation in extracellular protease production among clinical isolates of Staphylococcus aureus due to different levels of expression of the protease repressor sarA. Infect. Immun. 70:4239-4246.

24. Le Loir, Y., F. Baron, and M. Gautier. 2003. Staphylococcus aureus and food poisoning. Genet. Mol. Res. 2:63-76.

25. Martí, M., M. P. Trotonda, M. Á. Tormo-Más, M. Vergara-Irigaray, A. L. Cheung, I. Lasa, and J. R. Penadés. 2010. Extracellular proteases inhibit protein-dependent biofilm formation in Staphylococcus aureus. Microb. Infect. 12:55-64.

26. Martínez, B., J. M. Obeso, A. Rodríguez, and P. García. 2008. Nisinbacteriophage cross resistance in Staphylococcus aureus. Int. J. Food Microbiol. 122:253-258.

27. Ming, X., and M. A. Daeschel. 1993. Nisin resistance of foodborne bacteria and the specific resistance responses of Listeria monocytogenes Scott A. J. Food Prot. 56:944-948.

28. Nostro, A., R. Scaffaro, G. Ginestra, M. D'Arrigo, L. Botta, A. Marino, and G. Bisignano. 2010. Control of biofilm formation by poly-ethylene-co-vinyl acetate films incorporating nisin. Appl. Microbiol. Biotechnol. 87:729-737.

29. Oliver, S. P., B. M. Jayarao, and R. A. Almeida. 2005. Foodborne pathogens in milk and the dairy farm environment: food safety and public health implications. Foodborne Pathog. Dis. 2:115-129.

30. Peschel, A., M. Otto, R. W. Jack, H. Kalbacheri, G. Jung, and F. Götz. 1999. Inactivation of the dlt operon in Staphylococcus aureus confers sensitivity to defensins, protegrins and other antimicrobial peptides. J. Biol. Chem. 274:8405-8410.

31. Pinto, M. S., A. F. de Carvalho, A. C. S. Pires, A. A. C. Souza, P. H. F. da Silva, and D. Sobral. 2011. The effects of nisin on Staphylococcus aureus count and the physicochemical properties of traditional minas serro cheese. Int. Dairy J. 21:90-96.

32. Piper, C., L. A. Draper, P. D. Cotter, R. P. Ross, and C. Hill. 2009. A comparison of the activities of lacticin 3147 and nisin against drugresistant Staphylococcus aureus and Enterococcus species. J. Antimicrob. Chemother. 26:1-6.

33. Qi, X., G. Poernomo, K. Wang, Y. Chen, M. B. Chan-Park, R. Xu, and M. W. Chang. 2011. Covalent immobilization of nisin on multiwalled carbon nanotubes: superior antimicrobial and anti-biofilm properties. Nanoscale 3:1874-1880.

34. Rilla, N., B. Martínez, and A. Rodríguez. 2004. Inhibition of a methicillin-resistant Staphylococcus aureus strain in afuega'l pitu cheese by the nisin z-producing strain Lactococcus lactis subsp. lactis IPLA 729. J. Food Prot. 67:928-933.

35. Ross, R. P., S. Morgan, and C. Hill. 2002. Preservation and fermentation: past, present and future. Int. J. Food Microbiol. 79:3-16.

36. Salton, M. R. J. 1957. The properties of lysozyme and its action on microorganisms. Bacteriol. Rev. 21:82-99.

37. Samelis, J., A. Kakouri, K. J. Rogga, I. N. Savvaidis, and M. G. Kontominas. 2003. Nisin treatments to control Listeria monocytogenes post-processing contamination on Anthotyros, a traditional Greek whey cheese, stored at $4^{\circ} \mathrm{C}$ in vacuum packages. Food Microbiol. 20:661-669.

38. Schneider, N., K. Werkmeiser, C. M. Becker, and M. Pischetsrieder. 2011. Prevalence and stability of lysozyme in cheese. Food Chem. 128:145-151.

39. Shaw, L., E. Golonka, J. Potempa, and S. J. Foster. 2004. The role and regulation of the extracellular proteases of Staphylococcus aureus. Microbiology 150:217-228.

40. Stepanović, S., V. Djukić, V. Djordjević, and S. Djukić. 2003. Influence of the incubation atmosphere on the production of biofilm by staphylococci. Clin. Microbiol. Infect. 9:955-958.

41. Sudagidan, M., and A. Aydin. 2009. Screening virulence properties of staphylococci isolated from meat and meat products. Wien. Tierärztl. Monat. 96:128-134.

42. Sudagidan, M., C. Çavuşoğlu, and F. Bacakoğlu. 2008. Investigation of the virulence genes in methicillin-resistant Staphylococcus aureus strains isolated from biomaterial surfaces. Mikrobiyol. Bül. 42:29-39.

43. Suppakul, P., J. Miltz, K. Sonneveld, and S. W. Bigger. 2003. Active packaging technologies with an emphasis on antimicrobial packaging and its applications. J. Food Sci. 68:408-420. 